\title{
Usage of Information and Communication Technology in the Delivery of Agricultural Extension Services: A Case Study of Gedaref State, Sudan
}

\author{
Adam Elradi M. Ali ${ }^{1}$, Hamid E. E. Bashir ${ }^{2}$, Mohammed Adam A. Hamad ${ }^{3, *}$, Ahamed M. A. Berier ${ }^{1}$ \\ ${ }^{1}$ Department of Agricultural Extension and Training, University of Gezira, Sudan. \\ ${ }^{2}$ Sheikan Agricultural insurance Company, Gedaref State, Sudan. \\ ${ }^{3}$ Department of Rural Extension and Training, University of Kordofan, Elobeid, Sudan.
}

How to cite this paper: Adam Elradi M. Ali, Hamid E. E. Bashir, Mohammed Adam A. Hamad, Ahamed M. A. Berier. (2020) Usage of Information and Communication Technology in the Delivery of Agricultural Extension Services: A Case Study of Gedaref State, Sudan. International Journal of the Science of Food and Agriculture, 4(2), 211-218.

DOI: $10.26855 /$ ijfsa.2020.06.013

Received: May 11, 2020

Accepted: June 6, 2020

Published: June 28, 2020

"Corresponding author: Mohammed Adam A. Hamad, Department of Rural Extension and Training, University of Kordofan, Elobeid, Sudan.

Email: abugitaf2013@gmail.com

\begin{abstract}
The emergence of new agricultural development paradigms has led to challenging the conventional methods of delivering important services to farmers and the transformation of traditional societies into modern societies. Across the developing countries, agricultural is a major contributor to GDP and employment. The objective of this paper was to assess the use of ICTs in delivery of agricultural extension services in Gedaref State, Sudan. The primary data were collected from 94 extension officers represent total sample size in the Gedaref State in growing season2018/2019. Well-constructed questionnaire was used for data collection. The data were coded, fed to computer and statistically analyzed by using (SPSS) software, emphasized on descriptive statistics analysis and Chi-squire Test. The results indicated that the majority of the respondents (72.3\%) used ICTs and $47.8 \%$ of the extension officers used ICTs for audiences as multiple purposes services. Also $93.6 \%$ of the respondents faced more than one constraint when using ICTs. Results of chi-square test showed significant association between some ICTs (mobile phone, computer, digital camera, audiovisual aids, TV) and their purpose $(\mathrm{P}=0.001)$. Significant association between ICTs and constraints of using ICTs in delivery of agricultural extension services $(\mathrm{P}=0.001)$. This paper concluded that the use of ICTs in the delivery of agricultural extension services to extension clienteles in Gedaref State is still in the beginning stages according to the high percentage of using traditional ICTs such as TV in comparison to modern ICTs such as smart phone and internet websites. The paper recommends that more efforts should be exerted to train extension officers and beneficiaries on the active use of modern ICTs.
\end{abstract}

\section{Keywords}

Agricultural extension services, ICTs, Gedaref State, Sudan

\section{Introduction}

The agricultural sector of Sudan is the dominant sector of the Sudan's economy. The research has shown that the social and economic growth of Sudan depends to a great extent on the performance of the agricultural sector. In addition to generating directly about two-fifths of GDP, agricultural also drives activities in the industry and service sectors such as 
transportation, agro-industries, and commerce, which account for a large part of the rest of the economy. Even more importantly, 80 percent of the labor force is employed in agricultural and related activities. Also the performance of agricultural sector is the main determinant of year-to-year changes in poverty levels and the food security of the population of any country.

Before oil extraction in1999, agricultural was the source of virtually all of the Sudan's exports, and therefore, it is a key determinant of balance of payments developments. The agricultural resource base covers several agro-economic zones that include afforest, farmlands, arable croplands and grazing lands for livestock as well as fisheries in the Nile basin and in the Red Sea. The current cropped area is about 41 million Acers (17 million hectares) which account to about 20 percent of the potential arable lands [1].

Global attention came back to agriculture due to the price hike in recent years, resulting partly from long-standing negligence on diffusion of appropriate technology that stagnated production in the face of a rising population. Increasing production is a major challenge facing present agriculture. Smallholder farmers which dominate the landscape of developing world need to improve their farming business through acquiring adequate knowledge and information. Agricultural extension services provide critical access to the knowledge, information and technology that farmers require to improve the productivity and thus improve the quality of their levels of livelihoods. It is hence crucial to provide farmers with the knowledge and information in a quality and timely way. Although some ground-breaking tools like the tele-centres can serve as major catalysts for information, knowledge and development opportunities, the access of farmers in remote villages to information is restricted due to the lack of infrastructure [2]. The use of information and communication technology (ICT) in agricultural extension and rural development has significantly increased in many countries where it has provided a medium to adequate access to agricultural information [3].

Information and communication technology (ICT) can play a key role in increasing agricultural production, poverty alleviation, education and health of rural people. In Africa, ICTs can be seen as an important component of agricultural development they can be used as modern tools in the provision of needed information, knowledge and skills for improving agricultural productivity and rural incomes of African countries. Agricultural extension and advisory services organizations can help rural people to use these ICTs effectively that in turn will lead to increase their production efficiency, enhance food security and better standard of living [4]. The effective agricultural extension work rely on extension messages (information) reaching many farmers and farmer's problems reaching extension agents quickly and regularly [5]. Information and communication technologies (ICTs) have promising future to transform agricultural sectors and economic growth of developing countries. There for technologies that can be used in producing, organizing and distributing information [6]. In the vast of African countries agricultural extension services are weak, unsatisfactory or not exist.

In Sudan as in the most developing countries ministry-based agricultural extension services are adopted and established after the Second World War as part of American Aid for developing countries in1959. Therefore, agricultural extension services are still depend largely on the use of traditional communication methods in the delivery of these services to extension clientele [4]. When using traditional communication methods, extension officers cannot reach all the targeted clienteles because of long distances, bad roads, poor communication infrastructure in most rural areas in the country, low financial support in addition to high farmers extension officer ratio. In the majority of developing countries, there are few extension officers to serve many farmers, for example in Kenya the ratio of farmers to extension officer is 753:1 [7].

\section{Materials and Methods}

\subsection{Area of the study}

The Gedaref State is located in Eastern Sudan (longitude $13^{\circ} 51^{\prime} \mathrm{E}$ and latitude $34^{\circ} 55^{\prime} \mathrm{N}$ ) bordered by Kassala State at the north, Khartoum State at the northwest, Sinner State at the south, Gezira State at the west and Eritrea at the east. The state covers a total area of 75,263 Km2 [2]. It is 600 meters above the sea level. About 1,348,378 people live in Gedaref area according to 2008 Population census (Population Census Council, 2009). The average population density of Gedaref area was estimated at approximately 18 persons per square kilometer.

The area is generally divided into three agro-ecological zones on the basis of the amount of rainfall and main agricultural characteristics. The northern zone with rate of rainfall less than $500 \mathrm{~mm}$; where animals especially sheep production is primarily practiced beside crop production, the central zone with rainfall range between 500 to $600 \mathrm{~mm}$ and the southern zone with rainfall range between 600 to900 [2].

\subsection{Population and sample size}

The target population is the total number of agricultural extension officers working for Agricultural Extension and Technology Transfer Administration of Gedaref State is estimated to be 94 agricultural extension officers. This number represents the sample size of the study. 


\subsection{Data collection and analysis}

Field survey was used to collect data from 94 extension officers. A Close ended questionnaire consisting of twenty one questions was constructed and addressed socioeconomic characteristics of extension officers, kind of ICT used, purpose of use and constraints facing the use of ICT in the delivery of agricultural extension services to extension clienteles in Gedaref State. The personal interview technique was used to administer the questionnaire. A pre-test for the questionnaire was made with 15 extension officers.

The collected data were coded, fed to computer and statistically analyzed by using Statistical Packages for Social Sciences (SPSS), discussed and interpreted using percentage, frequency distribution and chi-squire test at $\mathrm{P} \leq 0.05=$ significance. Chi square is given by:

$$
\chi^{2}=\sum_{\mathrm{r}=1}^{\mathrm{R}} \sum_{\mathrm{c}=1}^{\mathrm{C}}\left(\mathrm{O}_{\mathrm{rc}}-\mathrm{E}_{\mathrm{rc}}\right)^{2} / \mathrm{E}_{\mathrm{rc}}
$$

With degrees of freedom (v) given by (R-1) (C-1), where:

R: Rows of the contingency table, C: Columns of the contingency table, O: Observed value, E: Expected value [8].

\section{Results and Discussion}

\subsection{Results of Descriptive analysis}

Table 1. Distribution of the extension officers according to their demographic characteristics

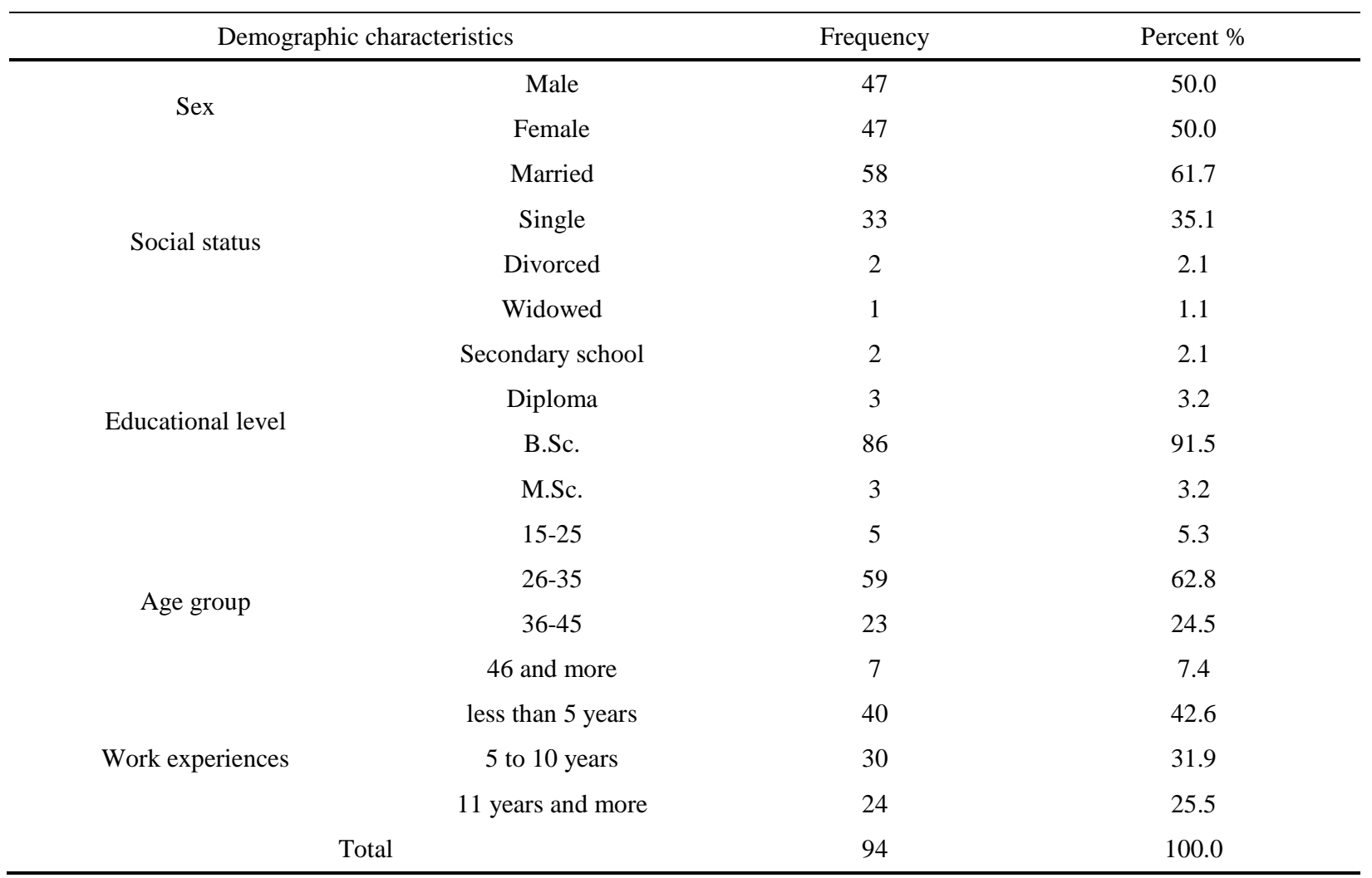

Table 1 showed that $50 \%$ of the extension officers were males, while $50 \%$ of theme were females this shows that the equal opportunities for appointment in the study area. The adopted agricultural extension approach should have gender sensitivity to keep suitable sex ratio among extension officers in order to cover the women farmers at farm level. Regarding values, norms, religion and traditions of rural people in Sudan extension organizations should recognize and respect the gender issue in their fields.

The majority of the extension officers (61.7\%) were married while $35.1 \%$, $2.1 \%$, and $1.1 \%$ of them were single, divorced and widowed respectively. In this paper, married people are more creative and have more stability in their work.

Results extend to indicate that the majority of extension officers (91.5\%) bachelor holders, compared to $3.2 \%$, and $3.2 \%$ of them are M.Ss and Diploma holders respectively. Only 2.1\% of them are secondary school certificate holders. Educational level of extension officers contributes directly to job performance and impact of extension work with rural 
people. Education level of extension officers is one of the most serious problems of extension in many countries.

In regard to age $62.8 \%$ of the extension officers between $26-35$ years old, $24.5 \%$ of them between $36-45$ years old, $5.3 \%$ of them between $15-25$ years old and $7.4 \%$ of them have 46 years old and more. Research showed that employing of young people can be cost effective and provide required skills and workforce in the future and a source of future management power.

Also, the results revealed that $42.6 \%$ of the extension officers reported that their work experiences less than 5 years. $31.9 \%$ of them reported that their work experiences 5-10 years and $25.5 \%$ of them reported that their work experiences 11 years and above. The work experience or period of appointment is essential for extension personnel. It will increase their ability, knowledge, skills, and behavioral dimensions which are important for the field level extension personnel, years of work experience help in the good management of the field and individuals and wok in a spirit of one team and this reflected positive possibility in production and productively.

Table 2. Distribution of the extension officers according to their use of ICT in the delivery of Agricultural Extension services

\begin{tabular}{ccc}
\hline Use of ICT & Frequency & Percent\% \\
\hline Use ICT & 68 & 72.3 \\
Did not use ICT & 26 & 27.7 \\
Total & 94 & 100.0 \\
\hline
\end{tabular}

Table 2 revealed that the majority of the extension officers (72.3\%) reported that they used ICT in the delivery of agricultural extension services to their audiences. While $27.7 \%$ of them reported that they did not use ICT in the delivery of agricultural extension services to their audiences. Farmer's demand for information has increased in recent years due to greater market instability, more complex production technologies among others. Lack of timely information can prevent good quality decision and thus lower the efficiency of production decision among farmers. Therefore, ICT can be used to strengthen the capabilities of rural development workers, farmers, farmer organizations and rural communities as a whole.

Table 3. Distribution of the extension officers according to the kind of ICT used in the delivery of agricultural extension services

\begin{tabular}{ccccccccccc}
\hline \multirow{2}{*}{ Kind of ICT used } & \multicolumn{2}{c}{ Computer } & \multicolumn{2}{c}{ Digital camera } & Audiovisual aids & \multicolumn{2}{c}{ Television } & \multicolumn{2}{c}{ mobile phone } \\
\cline { 2 - 11 } & Fre. & \% & Fre. & \% & Fre. & \% & Fre. & \% & Fre. & \% \\
\hline Not used & 32 & 34 & 50 & 53 & 33 & 35.1 & 31 & 33 & 26 & 27.7 \\
Often & 32 & 34 & 10 & 10.6 & 48 & 51 & 54 & 57.5 & 60 & 63.8 \\
Some times & 21 & 22.3 & 7 & 7.4 & 9 & 9.6 & 7 & 7.4 & 6 & 6.4 \\
Rarely & 9 & 9.7 & 27 & 29 & 4 & 4.3 & 2 & 2.1 & 2 & 2.1 \\
Total & 94 & 100 & 94 & 100 & 94 & 100 & 94 & 100 & 94 & 100 \\
\hline
\end{tabular}

Table 3 showed that: 34\%, 53\%, 35.1\%, 33\% and 27.7\% of the extension officers reported that they did not use computer, video, audio-visual aids, television and mobile respectively in the delivery of agricultural extension services to their audiences.

$34 \%, 10.6 \%, 51 \%, 57.5 \%$ and $63.8 \%$ of the extension officers reported that they often used computer, Digital camera, audio-visual aids, television and mobile phone respectively in the delivery of agricultural extension services to their audiences.

$22.3 \%, 7.4 \%, 9.6 \%, 7.4 \%$ and $6.4 \%$ of the extension officers reported that they used computer, video, audio-visual aids, television and mobile respectively some times in the delivery of agricultural extension services to their audiences.

$9.7 \%, 29 \%, 4.3 \%, 2.1 \%$ and $2.1 \%$ of the extension officers reported that they used computer, video, audio-visual aids, television and mobile respectively rarely in the delivery of agricultural extension services to their audiences.

The role of ICT in improving agricultural extension communication with beneficiaries to share information, skills, experiences and other purposes of communication was found to be the backbone of successful agricultural extension services that in turn will lead to the targeted agricultural development. 
Table 4. Distribution of the extension officers according to purposes for which ICTs were used

\begin{tabular}{cccccccccccc}
\hline \multirow{2}{*}{ Purpose of use of ICTs } & \multicolumn{2}{c}{ Computer } & \multicolumn{2}{c}{ Digital camera } & \multicolumn{2}{c}{ Audiovisual aids } & \multicolumn{2}{c}{ Television } & \multicolumn{2}{c}{ mobile } \\
\cline { 2 - 11 } & Fre. & $\%$ & Fre. & $\%$ & Fre. & $\%$ & Fre. & $\%$ & Fre. & $\%$ \\
\hline $\begin{array}{c}\text { Not used } \\
\text { extension methods }\end{array}$ & 32 & 34 & 50 & 53.2 & 35 & 37.2 & 33 & 35.1 & 26 & 27.7 \\
source of agricultural infor- & 25 & 26.6 & 15 & 16 & 30 & 31.9 & 35 & 37.2 & 12 & 12.8 \\
$\begin{array}{c}\text { mation } \\
\text { source of problem solving }\end{array}$ & 6 & 6.4 & 5 & 5.3 & 2 & 2.1 & 1 & 1.1 & 6 & 6.4 & \\
$\begin{array}{c}\text { practices } \\
\text { Multiple purposes }\end{array}$ & 7 & 7.5 & 6 & 6.4 & 3 & 3.2 & 00 & 00 & 5 & 5.3 \\
$\quad$ Total & 24 & 25.5 & 18 & 19.1 & 24 & 25.5 & 25 & 26.6 & 45 & 47.8 \\
& 94 & 100 & 94 & 100 & 94 & 100 & 94 & 100 & 94 & 100 \\
\hline
\end{tabular}

Table 4 indicates the followings: 34\%, 53\%, 35.1\%, 33\% and 27.7\% of the extension officers reported that they did not use computer, Digital camera, audio-visual aids, television and mobile respectively in the delivery of agricultural extension services to their audiences. $26.6 \%, 16 \%, 31.9 \%, 37.2 \%$ and $12.8 \%$ of the extension officers reported that they used computer, Digital camera, audio-visual aids, television and mobile respectively in the delivery of agricultural extension services to their audiences as extension methods. $6.4 \%, 5.3 \%, 2.1 \%, 1.1 \%$ and $6.4 \%$ of the extension officers reported that they used computer, Digital camera, audio-visual aids, television and mobile respectively in the delivery of agricultural extension services to their audiences as source of agricultural information. $7.5 \%, 6.4 \%, 3.2 \%, 0.0 \%$ and $5.3 \%$ of the extension officers reported that they used computer, Digital camera, audio-visual aids, television and mobile respectively in the delivery of agricultural extension services to their audiences as source of problem solving practices. $25.5 \%, 19.1 \%, 25.5 \%, 26.6 \%$ and $47.8 \%$ of the extension officers reported that they used computer, digital camera, audio-visual aids, television and mobile respectively in the delivery of agricultural extension services to their audiences for multiple purposes.

The use of ICTs in the delivery of agricultural extension services to extension audiences can have economic impact to their users because they can save time and money especially for those who do not prefer leaving their work sites and travel to near towns and cities to make their own purchases of agricultural inputs and other farm needs.

Table 5. Distribution of the extension officers according to constraints facing their use of ICT in the delivery of agricultural extension services

\begin{tabular}{ccc}
\hline Constraints facing the use of ICTs & Frequency & Percent \% \\
\hline Lack of ICT & 3 & 3.2 \\
Lack of technical know-how & 2 & 2.1 \\
High cost of using ICT & 1 & 1.1 \\
all constraints & 88 & 93.6 \\
Total & 94 & 100. \\
\hline
\end{tabular}

Table 5 revealed that $3.2 \%$ of the extension officers reported that they have no computer, video, audio-visual aids, television and mobile. $2.1 \%$ of the extension officers mentioned that they lack technical know-how which can help them to get more benefits from ICTs if they are trained in the proper use of them. $1.1 \%$ of the extension officers agreed that ICT have high cost including their prices and usage. And the majority of the extension officers (93.6\%) reported that they faced many other constraints in their use of ICT in the delivery of agricultural extension services such the lack of internet centers in some rural areas in the state and the lack of technical know-how among farmers in using some ICTs.

\subsection{Test of significance by using chi-square test:}

Table 6. Chi-squire test for association between mobile phone and the purposes of using it

\begin{tabular}{ccccc}
\hline Purpose of using mobile & \multicolumn{2}{c}{ Use of mobile } & \multirow{2}{*}{ Total } & \multirow{2}{*}{ Sig } \\
\cline { 2 - 3 } Not used at all & Yes & no & & 23 \\
As extension method only & 2 & 21 & 12 & 6 \\
As source of extension information only & 12 & 0 & 5 & .0001 \\
As source of problem solving practices only & 5 & 1 & 0 & 48 \\
More than one purpose & 5 & 4 & 94 & \\
\hline
\end{tabular}

Significance level at 0.05 or less 
Table 6 revealed that there was a significant association between mobile phone and the purposes of using it. This result I line with [9], he reported that majority of stakeholder used modern mobile phone for multi-purposes to improve their production.

Table 7. Chi-squire test for association between computer and the purpose of using it

\begin{tabular}{ccccc}
\hline Purpose of using computer & \multicolumn{2}{c}{ Use computer } & Total & Sig \\
\cline { 2 - 3 } Not used at all & Yes & No & 32 & .0001 \\
As extension method only & 8 & 24 & 25 & 6 \\
As source of extension information only & 24 & 6 & 7 & 24 \\
As source of problem solving practices only & 6 & 0 & 94 \\
More than one purpose & 7 & 23 & 26 & 98 \\
\hline
\end{tabular}

Significance level at 0.05 or less

The ICTs are a heterogeneous set of goods and services used to produce, process, distribute and transform information. The empirical literature acknowledges the benefits of ICTs on economic growth and positively correlates with Gross Domestic Product [10], the results in Table 7 showed that there was a significant association between computer and the purposes of using it.

Table 8. Chi-squire test for association between digital camera and the purposes of using it

\begin{tabular}{|c|c|c|c|c|}
\hline \multirow{2}{*}{ Purpose of using camera } & \multicolumn{2}{|c|}{ Use of digital camera } & \multirow{2}{*}{ Total } & \multirow{2}{*}{ Sig. } \\
\hline & Yes & no & & \\
\hline Not used at all & 23 & 26 & 49 & \multirow{6}{*}{.0001} \\
\hline As extension method only & 16 & 0 & 16 & \\
\hline As source of extension information only & 5 & 0 & 5 & \\
\hline As source of problem solving practices only & 6 & 0 & 6 & \\
\hline More than one purpose & 18 & 0 & 18 & \\
\hline Total & 68 & 26 & 94 & \\
\hline
\end{tabular}

Significance level at 0.05 or less

Table 8 indicates that there was a significant association between digital camera and the purposes of using it. The contributions of digital camera in increasing production is not separate from other ICTs also integral to economic development [11].

Table 9. Chi-squire test for association between audiovisual aids and the purposes of using it

\begin{tabular}{ccccc}
\hline Purpose of using audiovisual & \multicolumn{2}{c}{ Use of audiovisual aids } & Total & Sig. \\
\cline { 2 - 4 } Not used at all & Yes & No & 25 & 35 \\
As extension method only & 10 & 1 & 30 & 2 \\
As source of extension information only & 29 & 0 & 3 & .0001 \\
As source of problem solving practices only & 2 & 0 & 24 & 94 \\
More than one purpose & 3 & 0 & 26 & 68 \\
\hline
\end{tabular}

Significance level at 0.05 or less

Table 9 revealed that there was a significant association between audiovisual aids and the purposes of using it [12], assessed the impacts of audiovisual aids use on agricultural in Africa. Her study centered on how the development audiovisual aids in Niger affected the welfare of stakeholder. 
Table 10. Chi-squire test for association between TV and purposes of using it

\begin{tabular}{ccccc}
\hline Purpose of using T.V & \multicolumn{2}{c}{ Use of TV } & \multirow{2}{*}{ Total } & Sig. \\
\cline { 2 - 4 } Not used at all & Yes & no & & 33 \\
As extension method only & 8 & 25 & 35 & 1 \\
As source of extension information only & 34 & 1 & 0 & 25 \\
As source of problem solving practices only & 1 & 25 & 0 & 0 \\
More than one purpose & 0 & 0 & 94 \\
\hline
\end{tabular}

Significance level at 0.05 or less

The results in Table 10 agreed with [13] who stated that the access to agricultural information in Sudan continues to be challenging to farmers due to use of inadequate sources and traditional extension approaches such as TV and Radio. However, the rapid growth of modern ICTs usage in developing countries resulted in several advantages compared to other alternatives in term of costs, geographic coverage and ease of use.

\section{Conclusion and Recommendations}

The use of ICTs in the delivery of agricultural extension services to extension clienteles in Gedaref State is still in the beginning stages according the high percentage of using traditional ICTs such as TV in comparison to modern ICTs such as smart phone and internet websites. It found that lack of technical know-how, poor infrastructure, and the high cost of acquiring modern ICT devices were dominant in Gadaref State. The paper recommends that special programs should be designed for effective use of ICT in the delivery of agricultural extension services in the State, more integration efforts at various levels should be exerted to train extension officers and beneficiaries on the use of modern ICTs, the constraints facing the use of ICTs in the agricultural extension services in the State should be solved by all concerned partners.

\section{References}

[1] World Bank. (2003). Sudan: Country Economic Memorandum, Stabilization and Reconstruction report. Report No.26420-SU, Washington, D.C.

[2] UNDP (United Nations Development Programme). (2001). Human Development Report 2001: Making New Technologies Work for Human Development. New York, Oxford University PressVan Den Berg, H. and J. Jiggins. 2007. "Investing in Farmers - The Impacts of Farmer Field Schools in Relation to Integrated Pest Management." World Development. 35(4): 663-686.

[3] Richardson, D. (2003). Agricultural Extension Transforming ICTs. Championing universal access ICT Observatory 20033 - transforming Agricultural Extension. Paper presented at the WICC/CTA’s ICT Observatory, Wageningen.: CTA.35 Rogers, E. M.

[4] Abdel Rahman, A. M. and Mohamed E. Hamid. (2012). Influence of some socioeconomic characteristics on the use of information and communication technologies (ICT) by vegetable farmers in Gezira State. International Journal of Research in Management, Economics and Commerce vol. 2 (1), pp: 177-194.

[5] Orikpe, Ephraim A. and Gloria, O. (2013). Information and Communication Technology and Enhancement of Agricultural Extension Services in the New Millennium. Journal of Education and Social Research, 3 (4):155-159. 2013.

[6] Unagha, A. O. (2006). Towards an Information and Communication Technology Conscious Nigerian Society. In Uhegbus, A. N. (Ed), the Research Librarian: Journal of Nigerian Library Association, Abia State Chapter, 1(1).

[7] Kaushik, P. and Singh, N. (2004). Information Technology and Broad-Based Development: Preliminary Lessons from North India. World Development, 32, 591-607.

[8] Altae, Iman Hassan. (2012). How to determine the sample size, Faculty of physical Education, Bagdad University, Iraq. 
[9] Hamad, Mohammed A. A, Muneer Elyas, Siddig Eltahir, Adam Elradi M Ali, Adam M Hamdan, and Ahamed H Elsafi. (2018). "Efficiency of Using Smart-Mobile Phones in Accessing Agricultural Information by Smallholder Farmers in North Kordofan-Sudan.” 124: 52121-31.

[10] Verdier-chouchane, Audrey, and Charlotte Karagueuzian. (2016). "Moving towards a Green Productive Agriculture in Africa: The Role of ICTs.” 7(7): 1-12.

[11] Freeman, Kathlee. (2017). "ICT Use by Smallholder Farmers in Rural Mozambique: A Case Study of Two Villages in Central Mozambique.” Journal of Rural Social Sciences 32(2): 1-19.

[12] Henri, Abel-ratovo L, Rahelizatovo C Noro, Okello J Julius, Rasoarahona Fenosoa, and Rasoarahona Jean. (2012). "Ownership and Use of Mobile Phones for Agricultural Transactions by Traders: The Case of the Analanjirofo and Atsinanana Regions-Madagascar.” Journal of Agricultural Extension and Rural Development 4(10): 305-17. https://doi.org/10.5897/JAERD11.068.

[13] Karetsos, Sotiris. (2014). "Developing a Smartphone App for M-Government in Agriculture.” Journal of Agricultural Informatic 5(1): 1-8. https://doi.org/10.17700/jai.2014.5.1.129.

[14] National Bureau of statistics, Population Census Council. (2009). Sudan. 